Revue musicale OICRM

\title{
Teaching Stravinsky. Nadia Boulanger and the Consecration of a Modernist Icon, de Kimberly A. Francis
}

\section{Stefano Alba}

Volume 6, numéro 1, 2019

URI : https://id.erudit.org/iderudit/1062438ar

DOI : https://doi.org/10.7202/1062438ar

Aller au sommaire du numéro

Éditeur(s)

Observatoire interdisciplinaire de création et recherche en musique (OICRM)

ISSN

2368-7061 (numérique)

Découvrir la revue

Citer ce compte rendu

Alba, S. (2019). Compte rendu de [Teaching Stravinsky. Nadia Boulanger and the Consecration of a Modernist Icon, de Kimberly A. Francis]. Revue musicale OICRM, 6(1), 223-229. https://doi.org/10.7202/1062438ar d'utilisation que vous pouvez consulter en ligne.

https://apropos.erudit.org/fr/usagers/politique-dutilisation/ 


\title{
Teaching Stravinsky. Nadia Boulanger and the Consecration of a Modernist Icon, de Kimberly A. Francis
}

\author{
Oxford, Oxford University Press, 2015, 296 pages
}

\section{Stefano Alba}

Mots clés: Nadia Boulanger ; Pierre Bourdieu ; modernisme ; néoclassicisme ; Igor Stravinsky.

Keywords: Nadia Boulanger; Pierre Bourdieu; modernism; neoclassicism; Igor Stravinsky.

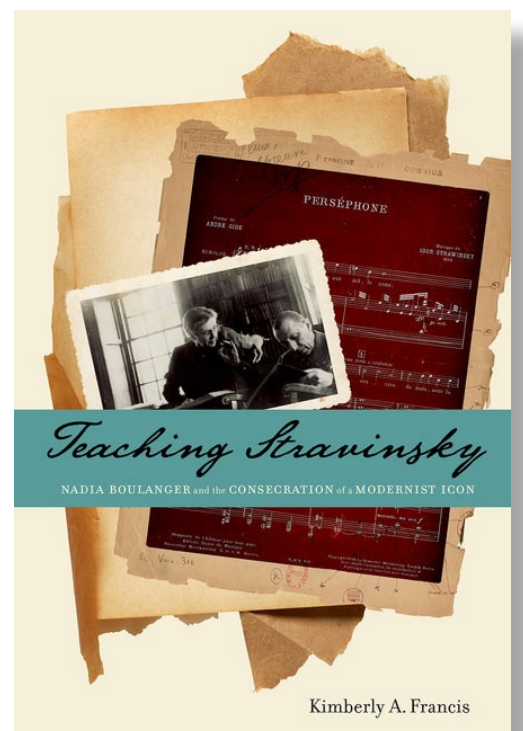

Nadia Boulanger, often overlooked in the previous musicological literature as a marginal figure in Igor Stravinsky's career, is reconsidered in Kimberly Francis's book as one of the key players in the consolidation of the composer's legacy. In this respect, the title Teaching Stravinsky acknowledges the centrality of her work as a pedagogue, but also serves as a double meaning that anticipates two main themes explored by the author. The first is Boulanger's role as the music teacher of Stravinsky's youngest son and aspiring pianist, Soulima. Francis demonstrates that the contact with him ultimately allowed Boulanger to enter the Stravinsky family's domestic sphere, which in turn led to an increasingly amicable connection with the composer himself. The second pivotal theme explored by Francis is the importance of her lectures in shaping the interpretation of Stravinsky's music for an entire generation of - mostly American-composers and musicologists. 
Most of the author's research has also focused on the position of Boulanger as one of the actors of French musical modernism. Her master's thesis explored Boulanger's work as a composer with the opera La ville morte $;{ }^{1}$ more recently, she contributed to the collective work Music Criticism in France, 1918-1939² with a study of Boulanger's early work as a critic for Le monde musical. Kimberly A. Francis has also edited a volume of Boulanger's correspondence with the Stravinskys, ${ }^{3}$ which already constituted one of the central sources of Teaching Stravinsky. The author is currently researching the compositional activity of Marcelle de Manziarly, herself a Boulanger alumna.

Francis's book is "first and foremost a feminist account of Boulanger's professional interactions with Stravinsky, his family, and his music" (p. 9). Citing as a source of inspiration the groundwork of feminist musicologists such as Marcia Citron, Annegret Fauser, Ellie Hisama, Carol Oja, and Judith Tick, the author's interest lies primarily in reconsidering the importance to the constitution of the modernist canon of those cultural actors - often women - that are frequently omitted in the "musicological narrative centered on the "Great Composer"' (p. 10). In order to do so, Francis turns to sociologist Pierre Bourdieu's theorization of the field of cultural production to reposition Boulanger's role behind the scenes in the establishment of Stravinsky's career and public image. Following this paradigm, she identifies Boulanger as an actor in the cultural field of modernism, and more specifically in support of the subfield of neoclassicism, of which Stravinsky's music became a symbol (p. 11). Using Bourdieu's theoretical framework, Boulanger is thus identified as an agent who possesses "the authority to define art," which results in the "consecration" of an artist, in this case Stravinsky, by means of the investment of a certain amount of "cultural capital" (p. 14).

It should be noted, however, that for a study that is purportedly presented through a sociological lens, Francis's narration of Boulanger's relationship with Stravinsky is a rather solipsistic one. Overall, the presentation leans more towards a biographical reconstruction of the intimate artistic and personal exchanges between these two key figures of $20^{\text {th }}$ century music, and provides only occasionally the bigger picture of the socio-cultural context in which they operated. In fact, the book proceeds with a history narrated in chronological order through a number of archival documents, but an external point of view to this story is virtually missing. The author returns to the Bourdieusian terminology intermittently, mostly in the form of brief paragraphs to recapitulate each chapter's events.

The lack of a broader context is particularly evident at some points of Francis's narration. One example is in the account of Boulanger's involvement with

1 Kimberly A. Francis (2005), Nadia Boulanger and La Ville Morte. En'gendering' a Woman's Role in the Making of an Opera, master's thesis, University of Ottawa.

2 Kimberly A. Francis (2018), "A Woman's Critical Voice. Nadia Boulanger and Le Monde musical, 1919-1923," in Barbara L. Kelly and Christopher Moore (Eds.), Music Criticism in France, 1918-1939. Authority, Advocacy, Legacy, Woodbridge, The Boydell Press, p. 169-191.

3 Kimberly A. Francis (Ed.) (2018), Nadia Boulanger and the Stravinskys. A Selected Correspondence, Rochester, University of Rochester Press. 
Stravinsky's melodrama Perséphone (1933) presented in Chapter 3 ("Surviving the Great Depression," p. 66-89). Citing Tamara Levitz's book Modernist Mysteries, ${ }^{4}$ the author mentions "Boulanger's participation in the Sapphic circles of interwar Paris," which was "of fundamental importance to sustaining the Sapphic notions inherent in the melodrama's materials" (p. 72). However, the reader is presented with this information without any notion on the nature of Parisian Sapphic circles, and also missing are the actual details of Boulanger's association with them. Perhaps more surprisingly, very little is said about the ideological contraposition of Stravinsky's music to that of Arnold Schoenberg, which could have helped contextualize Boulanger's strong advocacy of the former; this theme only appears towards the end, in Chapter 9 ("Mediating Serialism," p. 212-232), but more in relation to the later reception of serialism in post-WWII America. This is not to detract, however, from the actual historiographical interest of the author's work, which is the result of a remarkable rediscovery of previously unpublished sources from numerous European and American archives.

The author retraces the evolution of Stravinsky and Boulanger's relationship through a great number of letters, annotated scores, diaries, and other manuscripts, sometimes presented in their integrality. Most notably, the book's companion website ${ }^{5}$ offers several "explorations" where photographic reproductions of selected documents are made available for those who wish to delve into the details of Boulanger's analytical work.

The fil rouge that emerges clearly from Francis's book is that, starting with her attendance at the Parisian premiere of L'oiseau de feu in 1910, Boulanger became enamored with Stravinsky's music, to the extent that it perhaps represented a projection of her own musical vision, one she would embrace over the course of the century. She eventually became an ardent advocate of Stravinsky's neoclassical music, and it was particularly in the context of the classroom that she perpetuated her consecration. It remains unclear, however, to what extent her unceasing endorsement of Stravinsky's music remained an uninterested one. At times, one is led to question the sincerity of the obstinate defense of his neoclassical works, an aspect that did not go unnoticed by critics: Auguste Mangeot, the cofounder of the École normale de musique, where Boulanger taught, wrote in an article that while Stravinsky's Perséphone was not generally well received by the public and the critics, "since the very first day Mademoiselle Nadia Boulanger proclaimed that [it] was one of the greatest masterpieces of music [...] immediately [making] the score a part of history by analyzing it in her courses" (p. 74).

The authority and influence of Boulanger's field of cultural production found its consolidation in its transnational scope. The resonance of her work reached in particular the new generation of American composers. The origins of this transatlan-

4 Tamara Levitz (2012), Modernist Mysteries. Perséphone, New York, Oxford University Press, p. $396-473$.

5 See http://oup.com/us/teachingstravinsky, accessed 25 March, 2019. 
tic reach can be traced back as far as the start of World War I, as Nadia Boulanger helped found the Comite franco-américain, along with her sister Lili. The death of the latter on 15 March 1918, along with the aftermath of the war, represented a point of no return in Boulanger's artistic and personal life. Having abandoned a promising career as a composer, she turned to giving piano lessons at first, eventually leading to a decades-long career as a composition professor in Paris and in the United States. She was invited by Alfred Cortot as a professor of harmony at his newly established École normale de musique, the only woman in the composition department. From 1921, she joined the École des hautes études musicales de Fontainebleau (also known as the American Conservatory), a summer school that reinforced the Franco-American relations she helped promote at the start of the war. As Francis notes, "Boulanger soon drew the attention of a generation of American composers who arrived from Harvard, including her first star, Aaron Copland, as well as Virgil Thomson, Roy Harris, and Walter Piston" (p. 5).

As Stravinsky was in the midst of redefining his musical idiom towards neoclassicism when he returned to Paris from Switzerland in 1920, "Boulanger heralded his music as the future of modernism" (p. 7). It was at this time that the composer initiated a tradition of sending her copies of his scores as gifts, an aspect of their relationship that remains in the foreground of Francis's narration as a symbol of their friendship and shared artistic vision. In 1929, Stravinsky decided to engage Boulanger as a music teacher for his youngest son, Soulima. It is at this point that Boulanger's role gradually shifted from being a respected colleague to becoming a sort of member of the Stravinsky family. In fact, Francis argues that "Boulanger entered into sustained contact with the composer only after first becoming a sort of surrogate aunt to his sons and endearing herself to the female members of his immediate family" (p. 26). As a testimony of the level of Boulanger's involvement in the family's life, Francis uncovers a rather mundane anecdote from the Boulanger-Stravinsky correspondence. Soulima engaged in a sentimental relationship with Diantha Walker, also a student of Boulanger's, of which his parents did not approve. Francis has evidenced that, although cautious to stay explicitly on their son's side, Boulanger's diaries "reveal her sympathies remained with the couple" (p. 34).

One could be tempted to read perhaps too much into the events portrayed throughout the chapter, and to consider them as evidence of a singular relationship between Boulanger and Soulima. It is quite clear, however, that the teacher had a similarly intimate, quasi-maternal connection with others among her students. For example, she had been the godmother of Louise Talma on the occasion of her conversion to Catholicism in 1935 and, as Francis noted, "Boulanger would continue to act as a sort of second mother to the younger musician throughout their tumultuous relationship" (p. 55). Francis also mentions that Boulanger used to organize dinners and informal gatherings for her students, often as networking occasions.

The second chapter is particularly rich in archival documents, which Francis presents in order to reconsider Boulanger's influence on the interpretation of Stravinsky's music. The discovery of Louise Talma's transcriptions of Boulanger's Fontainebleau lectures offers a fascinating insight of her actual teaching practices. This didactical material also contains one of the earliest examples of her consecration 
of the neoclassical Stravinsky in the context of her pedagogical work: a lecture on his new Symphonie de psaumes, a work that she regarded as one of the composer's highest achievements. This composition also represented the first occasion for Boulanger to participate in the revision process of one of Stravinsky's scores. As his son Soulima was preparing a piano-vocal reduction of the work, Boulanger assisted him, and eventually took the task upon herself. It is in relation to this collaboration that Francis identified a proof of the extended resonance of Boulanger's analysis of Stravinsky's music. In 1973, Soulima was a professor at the University of Illinois and proposed the project for a revised edition of his father's piano works. According to Francis, "it is not too much of a stretch to consider Soulima's case for revision a repetition of Boulanger's rationale from the early 1930s" (p. 55). It should also be noted that his application was accompanied by a letter of recommendation from Boulanger, though it contained no references to her involvement with the revision of Stravinsky's scores.

As the relationship between the two evolved, in addition to publicly promoting his music, Boulanger began to secure commissions and teaching engagements for Stravinsky. In 1937, she embarked on a tour of the United States, where she was able to secure for herself a series of conferences, lectures, and concert performances, in part thanks to her network of former students. While in Washington, DC, she met with the wealthy patrons of the arts Mildred and Robert Woods Bliss, negotiating with them the commission for a Stravinsky composition that would eventually become the Dumbarton Oaks concerto, named after the Blisses' estate. Boulanger, from her privileged position as a confidante of the composer, was well aware of his worsening financial and familial situation, which culminated with the tragic loss of both his wife and his daughter to tuberculosis in 1939 (Chapter 4, "Beyond France," p. 90-106).

At the beginning of the 1940s, when both Stravinsky and Boulanger found themselves in exile in the United States, their relationship reached its apex. "It is at this point," Francis argues, "that Boulanger removes the mask of professionalism and treats Stravinsky as an intimate friend" (p. 127). Sharing a sense of incertitude over the future, "Stravinsky was no longer just her colleague; he was her only solace" (p. 128). Francis also mentions that, while teaching in the United States in 1941, Boulanger found herself amidst a feud with her former student Louise Talma over an anti-Semitic remark she allegedly made during one of her lectures. However, the episode remains rather unclear and the documents uncovered by Francis are not very helpful in clarifying this matter; yet it seems clear that the escalation of events contributed to her being viewed with suspicion by many of her former supporters overseas (p. 129). Another rather controversial issue is approached in the fifth chapter, namely the possibility of a romantic involvement between Boulanger and Stravinsky. While it is fairly surprising that apparently some of Boulanger's students hoped for her to marry him after his wife's death (p. 114), no actual evidence exists to confirm or deny the rumors. Francis's opinion on the subject is that "if Boulanger were to become Mme. Stravinsky after 1938, her career and ambitions would have been frozen. It is questionable whether, at the age of fifty-one, she was interested in reconfiguring her lifestyle to become Stravinsky's wife" (p. 116-117). Perhaps the author could have explored in greater detail the available information regarding her confirmed sentimental relationships; for example, towards the end of the book she 
casually mentions that the Prince Pierre of Monaco is now known to have been her lover (p. 220).

The years 1942-1945 saw a further consolidation of the artistic understanding between Stravinsky and Boulanger, particularly as the latter took a leave of absence from her teaching duties and moved closer to Igor and Vera Stravinsky on the West Coast. For this period of geographical closeness, their correspondence is less of an important source than the numerous annotated Stravinsky scores in Boulanger's collection. At this point, to quote Francis, "Stravinsky sent Boulanger scores as one would send greeting cards" (p. 138). This is a notable rediscovery on Francis's part, as these scores with Boulanger's annotations are actually part of the Stravinsky collection at the Bibliothèque nationale de France instead of hers. This moment is also particularly important because it marks the first time the composer dedicated one of his pieces to Boulanger, the Sonata for Two Pianos, completed in 1943 (p. 141).

While Boulanger's loyalty to Stravinsky's neoclassicism remained unaltered at the end of the war, when she returned to France she had to face an ongoing aesthetical debate over its validity. Since the late 1930s, the new generation of composers of La jeune France, guided by Olivier Messiaen, "linked accessible styles of music such as neoclassicism with the restrictions of national socialism" (p. 167). Quoting Leslie Sprout, Francis underlines that for the older generation of Stravinsky's supporters "the return was to an imaginary version of pre-war Paris, one where [his] new music had met with universal praise, not the mixed reception that had actually greeted the composer's final prewar appearance in the capital in 1938." ${ }^{6}$ While the composer himself would soon come to question the validity of his own neoclassical music, Francis argues that, at this point, Stravinsky still "relayed to Boulanger that she was of 'decisive importance' to the rehabilitation of his name in Europe" (p. 167).

The beginning of the 1950s saw a gradual decline of Stravinsky and Boulanger's symbiosis, as the composer moved on to serialism and Robert Craft rapidly emerged as Stravinsky's hagiographer. According to Francis, "Craft slowly insinuated himself into life with the Stravinskys in a manner reminiscent of Boulanger's own actions from the early 1930s" (p. 183). This is also a likely cause for the composer distancing himself from Boulanger around this time, as it has been evidenced that "Craft was in large part responsible for Stravinsky's alienation from colleagues, friends, and family after 1950" (p. 184). While Boulanger eagerly promoted his final neoclassical opera, The Rake's Progress (1952), "it became all too easy for Craft and others to convince Stravinsky that an association with her was becoming increasingly anachronistic and, to a degree, embarrassing" (p. 198). Perhaps most strikingly, for the first time, Stravinsky left unanswered Boulanger's requests for a copy of the score and expressed some irritation when he learned that she had managed to get one without his permission. Yet, the promise in Boulanger's reply-albeit sarcastic - not to loan, copy or perform the work without authorization (p. 199), might be what lay behind

6 Leslie A. Sprout (2009), "The 1945 Stravinsky Debates. Nigg, Messiaen, and the Early Cold War in France," The Journal of Musicology, vol. 26, n 1, p. 108. 
Stravinsky's concerns: after all, Francis mentions that at this point, Boulanger did not ask systematically for the composer's permission about usage of his scores. While he was aware of the work's in-progress status - something that had not dissuaded him from sharing his unrevised scores with Boulanger in the past-what troubled him now was perhaps his concern about Boulanger perpetuating an image of himself that he was starting to perceive as outdated.

In the last years of Stravinsky's life, Boulanger remained informed about him through a network of people close to him. Finding herself distanced from the Stravinskys and Craft, Boulanger turned once again to his children, particularly Théodore Stravinsky, a trust that continued well after the composer's death, as several legal battles arose (p. 240-244). While evidence of Boulanger's opinion of Craft is almost nonexistent, the growing concern regarding his role with Stravinsky can be sensed through the letters that she received, so one can only assume she was implicitly agreeing with them (p. 236). For example, Francis cites a 1969 letter by former Boulanger student Claudio Spies, reporting about Stravinsky's declining health: "It has become utterly impossible to understand how Mrs. Stravinsky can tolerate Craft's crude behavior toward Mr. Stravinsky, and the sadness at the old gentlemen's [sic] deterioration is thus the greater" (p. 240). Even his son Theodore voiced similar concerns:

Everything has been broken off between Vera and us following a letter that I could not stop myself from writing to her-in only the most correct and moderate terms - to tell her of my indignation at the announcement that not only all of the manuscripts but also all of the archives are up for sale. Letting others believe that it is Stravinsky himself selling all of them. Not to mention my indignation over the articles, or 'interviews,' fabricated by Craft to bolster the legend that the master is still mentally in full form. My letter earned me a vile response from Vera (p. 242).

As for Boulanger's relationship with Stravinsky's serial music, Francis has evidenced that she was more familiar with it than it was traditionally thought. Not only did she include it in her lectures, she also engaged in analysis of his music using serial techniques (p. 224), even though her loyalty to the neoclassical Stravinsky remained unaltered.

In conclusion, Francis's work stands out as an important step towards the discovery of how the "Great Composers" came to be-evidencing the amount of work that occurred behind the scenes in the construction, in this case, of Stravinsky as a "modernist icon." More specifically, the merit of Teaching Stravinsky lies primarily in the reconstruction of an oft-overlooked relationship between two key figures of French modernist music; but it also acts as a disciplinary self-reflection on the construction of musicological narratives. As Francis explained, Boulanger's analyses "sowed the seeds for a kind of theoretical writings and positions on Stravinsky and on music theory in general that would saturate much of the literature in the post-1950 American music-theoretical realm" (p. 251). 